\title{
O Twitter no rádio: as estratégias discursivas midiáticas de captura de ouvinte-internautas das rádios Gaúcha e Guaíba na cobertura do Grenal 408
}

\author{
Twitter on the radio: a study of media discourse strategies and capture \\ listener-Internet users in coverage the Grenal 408 on the Radios Gaúcha and \\ Guaíba
}

\section{Twitter en la radio: un estudio de estrategias mediáticas de captura de oyentes-usuarios de la red en las radios Gaúcha y Guaíba en la cobertura de lo Grenal 408}

Maicon Elias Kroth ${ }^{l}$

Fábio Giacomelli ${ }^{2}$

\begin{abstract}
Resumo
Este artigo analisa as estratégias discursivas midiáticas utilizadas pelas Rádios Gaúcha AM 600 FM 93.7 e Guaíba 720 AM 101.3 FM, para capturar ouvinte-internautas por meio da rede social Twitter. O referencial teórico-metodológico é fundamentado na discussão sobre o panorama do rádio contemporâneo e a adoção de redes sociais digitais pelo rádio, focando sua abordagem nos usos do Twitter. A análise evidenciou a construção de contratos de leitura por meio de uma proposta de produção de sentidos capaz de constituir vínculos com os ouvintes-internautas. A criação de hashtags, publicação de conteúdos da cobertura radiofônica especialmente organizada e a ênfase dada às performances dos narradores Pedro Ernesto Denardin (Gaúcha) e Marco Antônio Pereira (Guaíba) foram as principais estratégias identificadas para capturar a audiência.
\end{abstract}

\begin{tabular}{|c|c|}
\hline \multirow{3}{*}{ 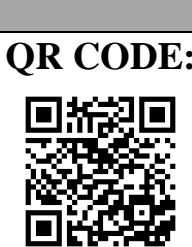 } & Acesse este artigo online \\
\hline & $\begin{array}{l}\text { Website: } \\
\text { http://www.revistas.ufg.br/index.php/ci }\end{array}$ \\
\hline & $\begin{array}{l}\text { DOI: } \\
\text { http://dx.doi.org/10.5216/ci.v20i2.39534 }\end{array}$ \\
\hline
\end{tabular}

Palavras-chave: Rádio. Twitter. Estratégias midiáticas.

\section{Abstract}

This paper analyzes the media discursive strategies used by Radios Gaúcha AM 600 FM 93.7 e Guaíba 720 AM 101.3 FM, to capture listener-Internet users through social network Twitter. The theoretical-methodological is based on the discussion of the panorama of contemporary radio and the adoption of digital social networks by radio, focusing his approach in Twitter uses. The analysis showed the construction of reading contracts through a proposal for the creation of meaning capable of forming bonds with listenersInternet users. The creation of hashtags, content publication of radio coverage organized and especially the emphasis on performances of storytellers Pedro Ernesto Denardin (Gaúcha) e Marco Antônio Pereira (Guaíba) were the main strategies identified to capture the audience.

\footnotetext{
${ }^{1}$ Pós-doutor em Ciências da Comunicação na Universidade da Beira Interior, Portugal, financiado pela CAPES. Doutor em Ciências da Comunicação pela Universidade do Vale do Rio dos Sinos - UNISINOS. Professor da Universidade Federal de Santa Maria. E-mail: maiconeliask@gmail.com

2 Investigador associado ao LabCom.IFP, unidade de investigação da área de Comunicação, Filosofia e Humanidades da Faculdade de Artes e Letras da Universidade da Beira Interior (UBI). Mestre em Jornalismo e Doutorando em Ciências da Comunicação na Universidade da Beira Interior, Covilhã, Portugal. E-mail: fabio@fabiogiacomelli.com.
} 
Keywords: Radio; Twitter; Media strategies.

\section{Resumen}

Este artículo analiza las estrategias mediaticas utilizadas por la Radio Gaúcha AM 600/FM 93.7 y la Radio Guaíba AM 720/FM 101.3, para capturar los oyentes-usuarios de la red, por medio de lo Twitter. El marco teórico-metodológico se basa en autores que tratan sobre la adopción de las redes sociales por la radio, centrando su enfoque en la utilización do Twitter. Análisis de contenido mostró la preocupación de los organismos de radiodifusión para ofrecer una cobertura deportiva diferenciada. Destacaron la organización particular de sus equipos deportivos durante el evento. Han creado hashtags para monitorear la cobertura radiojornalística por la red social y a través de él, destacar las actuaciones de los narradores Pedro Ernesto Denardin (Rádio Gaúcha) y Marco Antônio Pereira (Rádio Guaíba) como principales atractivos para el público seguir la transmisión por radio.

Palabras clave: Radio. Twitter. Estrategias mediáticas

\section{INTRODUÇÃO}

partir das lógicas do ecossistema midiático (SCOLARI, 2009), nos últimos anos, a
migração dos públicos para a internet tornou evidente a necessidade dos meios de
comunicação redirecionarem as suas dinâmicas de produção de conteúdos. Mas não bastaria apenas a preocupação em ressignificar a produção de conteúdo informativo. Era, também, preciso torná-lo atraente por meio de uma série de estratégias capazes de tornar mais eficiente a distribuição dos mesmos e despertar a atenção da audiência com vistas a otimizar o consumo. Este panorama, como não poderia deixar de ser, também se refletiu nas estratégias discursivas midiáticas de captura da audiência do rádio. $\mathrm{O}$ veículo incorporou novos serviços e conteúdos (CEBRIÁN HERREROS, 2011), em especial diante do uso das redes sociais digitais.

Diante deste cenário, este artigo analisa um caso específico da utilização da rede social Twitter por duas das principais emissoras de rádio do Rio Grande do Sul, Brasil. Trata-se das rádios Gaúcha AM 600 FM 93.7 e Guaíba AM 720 FM 101.3, localizadas em Porto Alegre. Ambas as empresas radiofônicas organizaram uma cobertura especial, multimidiática, para a transmissão do clássico entre Grêmio e Internacional. Tal cobertura foi amplamente midiatizada (KROTH, 2012) pelo Twitter e através de outros canais de comunicação das empresas mantenedoras das emissoras por meio de estratégias discursivas midiáticas (KROTH, 2010)

A pesquisa evidenciou o uso de enunciados lançados por meio do Twitter a serviço da captação de audiência para as rádios, tanto para o consumo das informações em plataformas digitais como para a transmissão radiofônica do jogo. Nesse sentido, este artigo tem como objetivo apresentar uma breve análise capaz de identificar as estratégias discursivas midiáticas 
e, por meio delas, como o uso do Twitter pode se constituir numa eficiente ferramenta de captura e fidelização da audiência radiofônica.

$\mathrm{Na}$ sequência do texto, há um quadro teórico que aborda um breve cenário contemporâneo das características do rádio. Também se discutem os conceitos de estratégias discursivas midiáticas. Em seguida apresenta-se as emissoras analisadas a partir da rede social Twitter. O percurso metodológico organizou-se de forma híbrida, à luz do contexto reflexivo sobre estratégias discursivas midiáticas e está explicitado junto à análise dos enunciados publicados no Twitter das duas emissoras radiofônicas entre os dias 20 e 22 de novembro de 2015 .

\section{ESTRATÉGIAS DE CAPTURA DA AUDIÊNCIA NO RÁDIO}

O rádio não deve ser considerado como um meio de comunicação isolado dos demais, mas sim inserido em um ecossistema comunicativo mutante (CEBRIÁN-HERREROS, 2011), complexo e dinâmico, que incorpora plataformas comunicativas diferentes, mas que convergem. Na contemporaneidade, o rádio caracterizado como hipermidiático (LOPEZ, 2009), vem transformando-se a partir do processo de convergência das mídias e explora cada vez mais novas linguagens (MANOVICH, 2006) e formatos possibilitados pela hibridização de formas simbólicas desenvolvidas para a difusão em multiplataformas (FERRARETO, 2010).

É evidente dizer que o rádio reorganizou-se em torno de características da multimidialidade (SALAVERRÍA, 2005), especialmente quando o meio de comunicação pode ser consumido na internet. $\mathrm{Na}$ web, há a possibilidade para o desenvolvimento de novos produtos radiofônicos (CEBRIAN-HERREROS, 2001), projetados para a renovação dos modos de consumo de mídia. Como em outros momentos da história do rádio, mais uma vez a tecnologia afeta positivamente o veículo. A produção de conteúdos ganha em qualidade, a transmissão é mais eficaz e potencializada pelos distintos suportes tecnológicos disponíveis e, nessas condições, a recepção também sai ganhando, com mais facilidades de acesso e ampliação dos canais de interação.

Neste contexto, novas possibilidades se abrem para o rádio a partir do uso das redes sociais, as quais foram incorporadas às lógicas de produção, constituindo-se em novos canais de interação e de espalhamento dos conteúdos. Há uma reorganização dos modos de produção direcionados para a atração de ouvinte-internautas cada vez mais conectados às redes sociais digitais. Prata, Campelo e Santos (2010, p.15) já afirmavam que hoje algumas empresas "sofisticaram sua forma de atuação e as redes sociais têm sido utilizadas para conhecer a 
opinião do público, responder reclamações e até como um balcão de um SAC (Serviço de Atendimento ao Consumidor) virtual. Isto é, rede social passou a significar estratégia de negócio".

Nessas condições, uma das mais importantes características do rádio, a interatividade com sua audiência foi potencializada. $\mathrm{O}$ veículo passou a adotar estratégias de interatividade assíncrona (LOPEZ, 2010), ofertando aos ouvintes um espaço de participação que, mesmo sendo controlado, se amplia com a evolução dos meios de comunicação interpessoal, como os aparelhos celulares e a possibilidade de acesso à internet.

Uma das maneiras de dinamizar os fluxos interativos entre as gramáticas de produção e recepção radiofônicas (KROTH, 2012) é o acesso, por parte dos ouvintes, às redes sociais. O ouvinte-internauta é "convidado a participar", é cada vez mais ativo, um coprodutor de conteúdos (KROTH, 2012). Outros pesquisadores da radiomorfose (PRATA, 2008) coadunam com a ideia de que as redes sociais estabelecem um novo espaço de troca de informações desses meios de comunicação com o público consumidor. Para Lopez (2010, p. 115), as redes sociais como o "Facebook, Flickr, Twitter, entre outros, se estabelecem como ambientes de troca, em que o espaço de fala é permitido a ambos, aproximando-os, de certa maneira".

As redes sociais, nessas condições, já podem ser consideradas os principais canais de interação para o estabelecimento de diálogos como os ouvintes-internautas. Muitas vezes disponíveis na palma da mão, por meio dos dispositivos móveis, as redes sociais se constituem como um lugar de estímulo à conversação, algo comum no rádio. Assim, a possibilidade de constituir um circuito interativo por meio dos dispositivos midiáticos se torna estratégico na relação que se pretende estabelecer - vinculação e de fidelização - com a audiência do rádio (KROTH, 2012).

A ideia da construção de ouvintes ao redor de discursos especialmente criados pelo campo de produção radiofônica para estabelecer conexões com a audiência, por identificação, é diagnosticada por Kroth (2010) com uma estratégia da mídia. Ainda segundo o autor, a ação de fazer uso de enunciados possíveis de causar reconhecimento envolve o receptor num sistema de cumplicidade. Neste sentido, o estabelecimento de uma relação entre o campo emissor e receptor pode se dar a partir de contratos de leitura (VERÓN, 2004). A explicação do autor refere-se às propriedades do discurso que permitem a um suporte criar e manter uma relação com seus receptores ao longo do tempo. Esta relação estaria baseada em uma noção de confiança construída a partir de estratégias discursivas da mídia. 
Os estudos de Fausto Neto (1995) também podem servir para explicar o conceito de contratos de leitura. O autor define como "contratos de leitura", a existência de dispositivos que "[...] funcionam como espécie de 'apanhamentos', 'assédios', 'capturas' do receptor, feitos no âmbito e na especificidade dos discursos [...]” (FAUSTO NETO, 1995, p.199). O contrato de leitura pode ser compreendido como uma proposta estratégica de produção de sentidos, dos meios de comunicação, cujos discursos são organizados de acordo com as particularidades de cada suporte, em função de um público receptor.

Os enunciados lançados pelo campo de produção radiofônica são capazes de construir em seu redor uma rede de experiências compartilhadas. O discurso forma uma espécie de estímulo de relações que se constrói em torno de um sentido comum. Em fluxo contínuo, as trocas de narrativas radiofônicas entre as gramáticas de produção e recepção colocam em marcha um novo conceito de comunidade de usuários (VIDELA-RODRÍGUEZ, PIÑEIROOTERO, 2013), que se estrutura a partir de novas fórmulas de participação baseadas numa arquitetura de interatividade cada vez mais colaborativa e que é estimulada por meio das redes sociais.

Nesse cenário, as redes sociais funcionariam como se fossem "elos" organizados pelo discurso colocado em ação pelos diversos sujeitos presentes na semiose hipermidiática e que estabelecem, assim, como efeito, os 'contratos de leitura' com o campo da recepção. Quando acopladas ao sistema operativo de interação do rádio, são utilizadas como dinamizadoras de circuitos discursivos, ou "pontos de articulação" em termos de estratégias de produção de sentidos (KROTH, 2012).

Por sua vez, por meio dos enunciados publicados nas redes sociais, o rádio aproxima ainda mais da sua audiência os grandes acontecimentos dignos de serem noticiados, como o presente caso, um clássico que reúne os dois maiores times de futebol do Estado do Rio Grande do Sul, no qual as duas emissoras estão inseridas. Nas transmissões de grandes acontecimentos, como o que se aborda neste artigo, uma das redes sociais que ganha visibilidade e importância é o Twitter.

\section{ESTRATÉgIAS DISCURSIVAS MIDIÁticas DAS RÁDIOS GAÚCHA E GUAÍBA NO TWITTER}

O Twitter foi criado em 2006 e é um site de rede social. Funciona a partir da criação de uma conta pelo usuário, que o permite publicar mensagens textuais (tuítes) de até 140 caracteres que podem incluir hiperlinks, hashtags, fotografias e pequenos vídeos. Na rede 
social, cada usuário pode personalizar os conteúdos que quer receber (PALÁCIOS, 1999) a partir da escolha de quem seguir. Escolhido o perfil, o usuário constrói a sua linha do tempo e forma a sua rede social oferecida pela ferramenta (RECUERO E ZAGO, 2009).

No Brasil, o Twitter começou a ser utilizado em 2009, mas foi no ano de 2010 que começou a aparecer como uma mídia suporte para os meios de comunicação convencionais (ROCHA, 2010). A facilidade de comunicação oferecida pela ferramenta possibilita a jornalistas o envio de informações com brevidade dos locais dos acontecimentos. Isso fez do Twitter um aliado para os meios de comunicação. A partir de um smartphone com o aplicativo da rede social, o jornalista é capaz de publicar de forma instantânea a notícia, em mensagens textuais ou ainda com suporte multimídia, o que a torna uma ferramenta eficiente na distribuição de notícias.

Como o Twitter oferece suporte apenas para mensagens curtas, muitas vezes os jornalistas trabalham com publicações sequenciais, narrando o acontecimento em uma série de tuítes que vão dar conta do relato completo da informação. Outra situação bastante comum de usabilidade da rede social em práticas jornalísticas é a utilização das hiperligações (CANAVILHAS, 2014), ou seja, o tuíte serve de lead ou manchete e a sequência apresenta um hiperlink que redirecionará o usuário da rede para outros suportes das empresas de comunicação, como os seus portais noticiosos.

Uma das grandes vantagens da utilização do Twitter pelos meios de comunicação é o compartilhamento das informações. Um tuíte, publicado por um perfil tem como destino os seus seguidores. Se um desses seguidores retuíta a publicação, esta mensagem chega aos perfis de quem segue este outro sujeito, criando uma rede na qual um simples tuíte pode chegar a milhares de usuários, mesmo que estes não sigam o perfil originário da informação.

Especificamente no rádio, o Twitter destaca-se por ser funcional para o campo da produção radiofônica, à medida em que não é apenas utilizado como uma ferramenta de criação de conteúdos, mas de mensuração de público ouvinte através da participação destes, pela rede social, durante a programação. "O twitter age como um termômetro instantâneo da audiência, com as reações e comentários sobre o que está no ar naquele momento feitos pelo público" (LOPEZ, 2010, p.103). Outra característica importante é a potencialização da interação por meio da rede social. Segundo Haussen (2010), o Twitter vem ocupar lugar de destaque nas interações radiofônicas, que permaneciam dependentes das ligações telefônicas e, sobretudo, de uma interatividade que era meramente reativa via SMS, no telefone celular. 
O papel do Twitter nos modos de produção do radiojornalismo também é evidente. Em pesquisa sobre as mudanças na rotina produtiva a partir do uso do Twitter na Rádio Gaúcha, Santos (2013) analisou que as novas tecnologias da informação reorganizam a configuração do trabalho do jornalista. Proporcionam maior controle, produtividade e modificações no fazer do trabalhador, e esse, por sua vez, adaptou-se a esse novo contexto.

A pesquisa revela que a emissora reviu planos de ação e práticas de produção com o objetivo de não perder ouvintes e conquistar o público que não tem o hábito de acompanhar rádio de notícias - especialmente jovens de até 25 anos. A apropriação do Twitter pela emissora significou mais do que a agregação de uma nova plataforma para divulgar informação.

Agora, em uma cobertura - especial ou de rotina, os repórteres entram no ar, tuitam, fotografam, produzem vídeos e textos para diversas plataformas. A apropriação do Twitter pela Rádio Gaúcha é a representação viva do jornalismo multimídia e multiplataforma (SANTOS, 2013, p.119).

Num outro exemplo de análise sobre o uso do Twitter pelo rádio, a rede social foi utilizada para a formação da programação da Rádio CBN Campinas. Neste caso, Cagliari e Zanotti (2012) verificaram que a rede social foi pouco utilizada como dispositivo de conversação com os ouvintes, e que "mesmo que a CBN Campinas demonstre, ao seu público, o interesse de estar nas redes, ainda não registra uma dedicação no sentido de fortalecer o contato com os ouvintes". (p.10).

Já ao observarem as aplicações das ferramentas digitais na comunicação ouvinteemissora durante a cobertura realizada pelas rádios CBN, de São Paulo, e Gaúcha, de Porto Alegre, nos dois turnos das eleições de 2014, (FLECK; FERRARETTO, 2015) consideraram que as emissoras identificam o momento de confluência das mídias e exploram novas formas de comunicação com o ouvinte e de geração de conteúdo, expandindo-se para as plataformas digitais. No caso do uso do Twitter, de maneira específica, observaram que a rede social foi utilizada de forma estratégica para reforçar a marca da Rádio Gaúcha junto à sua audiência. No entanto, a CBN gerou menos conteúdo por meio do dispositivo midiático, “centrando sua estratégia em chamar o ouvinte para ouvir a rádio, acessar a matéria no site ou baixar comentários em podcast" (FLECK, FERRARETTO, 2015, p.14).

Antes do uso de microblogs como o Twitter, afirma Kischievsky (2012) o comunicador detinha o poder de impor uma agenda de discussões, e ao ouvinte restava pouca margem de contestação. Já com o serviço de microblogging, é possível o estabelecimento de 
um "diálogo menos passível de controle por parte da emissora, já que o ouvinte pode interpelar o comunicador em mensagens diretas (privadas) ou de forma pública, irrompendo em sua linha de tempo e contestando informações ou simplesmente cumprimentando-o (p.3)”.

\section{AS RÁDIOS GAÚCHA E GUAÍBA, DE PORTO ALEGRE- RS}

A Rádio Gaúcha AM 600 FM 93.7 foi fundada em fevereiro de 1927 e operou, inicialmente, na frequência de $680 \mathrm{kHz}$. Em meados da década de 1980, com a aquisição da Rádio Farroupilha, que utilizava a frequência de $600 \mathrm{kHz}$, por parte do Grupo RBS, as emissoras trocaram de prefixo entre si. Seus estúdios estão sediados em Porto Alegre, capital do Rio Grande do Sul e a emissora é a cabeça de rede da Rede Gaúcha SAT, que conta com outras 160 emissoras que retransmitem seu sinal.

A Rádio Gaúcha possuí dois perfis no Twitter. Um oficial (@RdGaucha) e um esportivo (@FuteboldaGaucha). Este último foi o escolhido para esta análise. A conta do Futebol da Gaúcha foi criada no dia 27 de setembro de 2012 e, até o dia desta análise, 24 de novembro de 2015, contava com 70.192 tuítes postados, 58.794 seguidores e seguia apenas 267 contas, em sua grande maioria jornalistas da emissora e rádios parceiras.

A Rádio Guaíba 720 AM 101.3 FM, por sua vez, foi fundada em abril de 1957 e pertencia ao Grupo Caldas Júnior. Foi a única emissora do Rio Grande do Sul a cobrir o Mundial de Futebol de 1958, quando a seleção brasileira de futebol conquistou seu primeiro título. Desde então, passou pela mão de outros proprietários e hoje pertence ao Grupo Record, com sede em São Paulo. É cabeça de rede da Rede Guaíba SAT que conta com emissoras do interior do Rio Grande do Sul e de Santa Catarina que redistribuem seu sinal.

Da mesma forma que a Gaúcha, a Guaíba também conta com um perfil oficial (@RdGuaibaOficial) e com um esportivo (@GuaibaEsportes), que é o que será utilizado neste estudo. A conta do Guaíba Esportes foi criada no dia 14 de abril de 2014 e, até este levantamento, realizado também no dia 24 de novembro, contava com 33.382 tuítes postados, 16.487 seguidores e seguia 182 contas (todas com alguma relação com o jornalismo da emissora e/ou o esporte).

\section{ESTRATÉGIAS DISCURSIVAS MIDIÁTICAS DAS RÁDIOS GAÚCHA E GUAÍBA NO TWITTER}

$\mathrm{Na}$ observação proposta, adotou-se uma metodologia híbrida de investigação, que reuniu pesquisa bibliográfica, audição direta da programação radiofônica das duas emissoras e 
interpretação dos enunciados publicados nos perfis do Twitter das rádios. A observação se desenvolveu a partir da identificação e descrição analítica do que se considerou como estratégias discursivas midiáticas, fundamentado na abordagem teórica apresentada em capítulo específico no texto.

A análise desta pesquisa enfocou os conteúdos postados nos perfis @FuteboldaGaucha e @GuaibaEsportes, que concentram as publicações destas rádios no Twitter durante a cobertura do clássico entre Grêmio (0) e Internacional (1), que ocorreu no dia 22 de novembro de 2015, no Estádio Beira-Rio, pela 37ª rodada do Campeonato Brasileiro de Futebol, e que foram atualizadas pelos jornalistas das equipes esportivas de ambas as rádios.

Ao total, somou-se 293 tuítes feitos pelo perfil esportivo da Rádio Gaúcha e 282 postagens pelo perfil da Rádio Guaíba. Os dados apresentados nessa pesquisa foram obtidos por meio da ferramenta de mensuração de tuites, Topsy ${ }^{3}$. Neste período, identificou-se publicações no Twitter que remetessem à cobertura do acontecimento esportivo. Na figura 1, os gráficos apresentam o período de análise e o número de postagens feitas por cada emissora. $\mathrm{O}$ aumento do número de publicações no período analisado justifica a amostragem da pesquisa.

Figura 1. Número de tuítes por dia de análise. Gráficos oriundos da ferramenta online Topsy

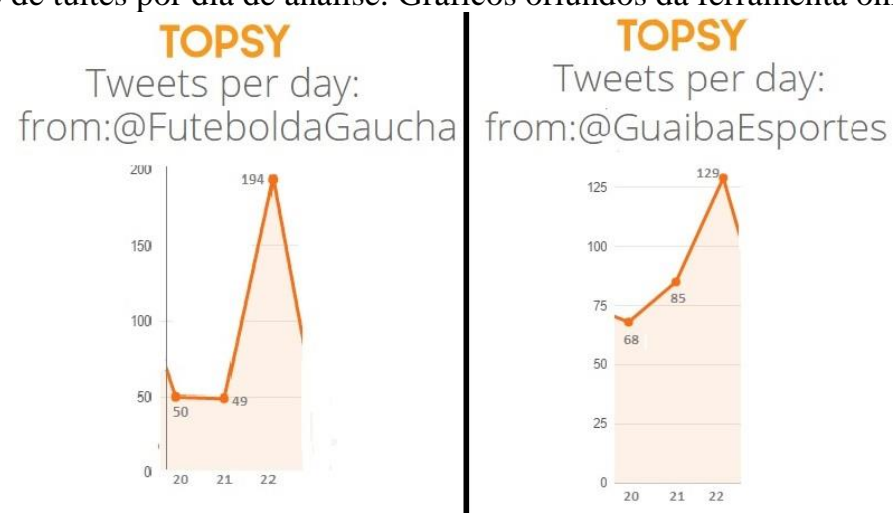

Fonte: www.topsy.com

As emissoras analisadas fazem uso do Twitter para propagar seus conteúdos e tentar captar os seus seguidores da rede social para o consumo dos mesmos e, também, atraí-los para a cobertura radiofônica possível de ouvir em qualquer dispositivo tecnológico. Tendo como base as publicações no perfil esportivo das emissoras no Twitter nos dias 20, 21 e 22 de

\footnotetext{
${ }^{3}$ Acesso disponível em: www.topsy.com
} 
novembro, que possuem como temática o clássico Gre-Nal, foi possível classificá-las a partir de macro divisões que foram comuns para os tuítes de ambas as rádios.

A classificação das postagens foi organizada a partir de categorias, as quais se constituem como estratégias discursivas midiáticas. São elas: a categoria Hashtag (reúne todas as postagens das rádios que tragam, nos tuítes, o uso desta ferramenta para agrupar todas as publicações); e Menções ao Narrador (posts que fazem referência à performance dos narradores usada pelas rádios para atrair os ouvintes). A Gaúcha enfatiza a performance de Pedro Ernesto Denardin, que narra seu $76^{\circ}$ Gre-Nal, enquanto a Guaíba estreia Marco Antônio Pereira e massifica essa divulgação em seus programas; a categoria Cobertura Esportiva, na qual estão classificadas as postagens que referem-se às publicações feitas no Twitter no período entre o pré e pós-jogo e, ainda, a categoria RT's da equipe esportiva, que reúne as postagens as quais se referem diretamente aos tuítes feitos pelos jornalistas de cada emissora e que foram retuítadas pelos perfis esportivos analisados neste artigo.

É importante ressaltar que alguns tuítes foram classificados em mais de uma categoria, devido à natureza do conteúdo, o que acarretará em números diferentes aos das publicações se os mesmos forem somados.

Tabela 1 - Categorização dos tuítes publicados pelas emissoras de rádio

Rádio Gaúcha

\begin{tabular}{|c|c|c|c|}
\hline \#GreNalnaGaúcha & $\begin{array}{c}\text { Menções } \\
\text { ao } \\
\text { Narrador }\end{array}$ & $\begin{array}{c}\text { Cobertura } \\
\text { Esportiva }\end{array}$ & $\begin{array}{c}\text { RT’s da Equipe } \\
\text { Esportiva }\end{array}$ \\
\hline 258 & 11 & 158 & 167 \\
\hline
\end{tabular}

Rádio Guaíba

\begin{tabular}{|c|c|c|c|}
\hline \#LigaNaGuaíba & $\begin{array}{c}\text { Menções ao } \\
\text { Narrador }\end{array}$ & $\begin{array}{c}\text { Cobertura } \\
\text { Esportiva }\end{array}$ & $\begin{array}{c}\text { RT's da Equipe } \\
\text { Esportiva }\end{array}$ \\
\hline 278 & 19 & 130 & 87 \\
\hline
\end{tabular}

\subsection{A RÁDIO GAÚCHA AM 600 E FM 93.7}

Para a cobertura especial do jogo no Twitter, a emissora lançou uma série de estratégias discursivas com vistas a estruturar uma rede de vínculos com os ouvintesinternautas. A primeira delas foi a criação de uma hashtag (\#) exclusiva para o clássico GreNal (\#GreNaldaGaucha). 
Figura 2. Hashtag (\#) utilizada na cobertura da Rádio Gaúcha

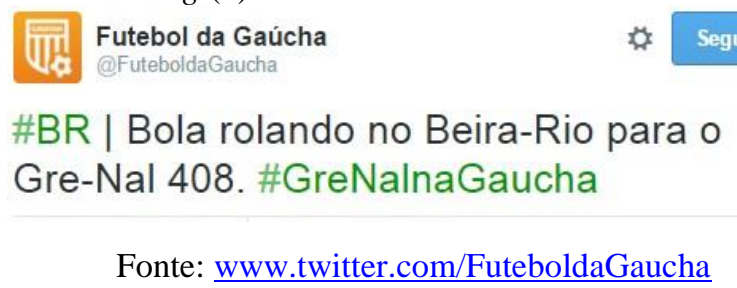

Na figura 2, a emissora propõe o contrato de leitura entre radio e internauta, anunciando o início da partida e disponibilizando a hashtag para que o usuário, ao clicar nela, seja direcionado ao conjunto de publicações relacionadas ao jogo de futebol e a cobertura esportiva da rádio. Para a emissora, isso significa a possibilidade de mensurar o nível de interação que ocorreu a partir do número de mensagens remetidas pelos ouvintes-internautas (LOPEZ, 2009). Isso também permite o filtro das mensagens, ou seja, a capacidade de agrupar conteúdos a partir da palavra-chave que constitui a hashtag. Como a hashtag não é de uso exclusivo da emissora, a Rádio Gaúcha poderia, através de retuítes, ampliar a visibilidade dos conteúdos publicados com a mesma, porém, no período analisado, não se observou tal estratégia. A \#GreNaldaGaucha somou 1.274 menções.

Nos tuites da Rádio Gaúcha, a análise percebeu que algumas das mensagens publicadas enfatizaram a performance do narrador do jogo, Pedro Ernesto Denardin, denominando-o como o "Homem Gre-Nal", inclusive, em alguns momentos, utilizando uma hashtag específica: \#HomemGreNal e, também, publicando uma hiperligação, que remetia ao portal da Rádio onde a transmissão poderia ser ouvida.

A ênfase dada ao narrador somou 11 tuítes, que partiram do perfil oficial da emissora e também dos jornalistas da Rádio Gaúcha. A Gaúcha focou a produção de discursos a partir do nome de Pedro Ernesto Denardin, nos diversos canais de comunicação do Grupo RBS. O objetivo foi construir uma espécie de espaço relacional entre o narrador e os ouvintesinternautas junto ao público (KROTH, 2012).

Figura 3. Tuíte destaca a figura do narrador da emissora 
Acompanhe a Jornada Esportiva com o Homem Gre-Nal, @pedroernestoRS ow.ly/UWpgY \#GreNalnaGaucha

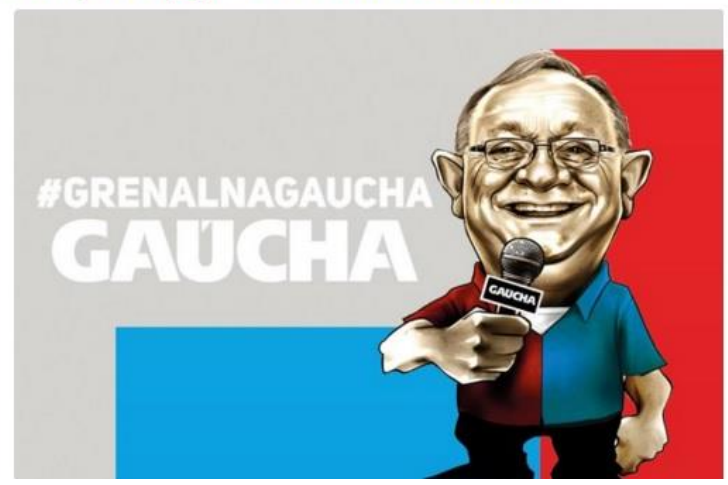

Fonte: www.twitter.com/FuteboldaGaucha

A emissora pretendeu captar a audiência por meio das diversas estratégias discursivas comumente utilizadas na cobertura de eventos esportivos. Entretanto, nessa oportunidade, o conteúdo veiculado explorou, de forma peculiar e contundente, as qualificações da performance do narrador e sua trajetória na história do jogo (narrou 76 Gre-Nais), sugerindo que a transmissão da emissora seria mais especial do que a das emissoras concorrentes, por causa de suas habilidades. Isso pode ser observado no tuite (figura 4), onde, primeiro a repórter Kelly Matos apresenta reportagem publicada no jornal Zero Hora e depois o perfil esportivo da rádio reafirma essa força em cima das habilidades de transmissão de Denardin.

Figura 4. O narrador foi midiatizado em outros meios de comunicação do grupo RBS
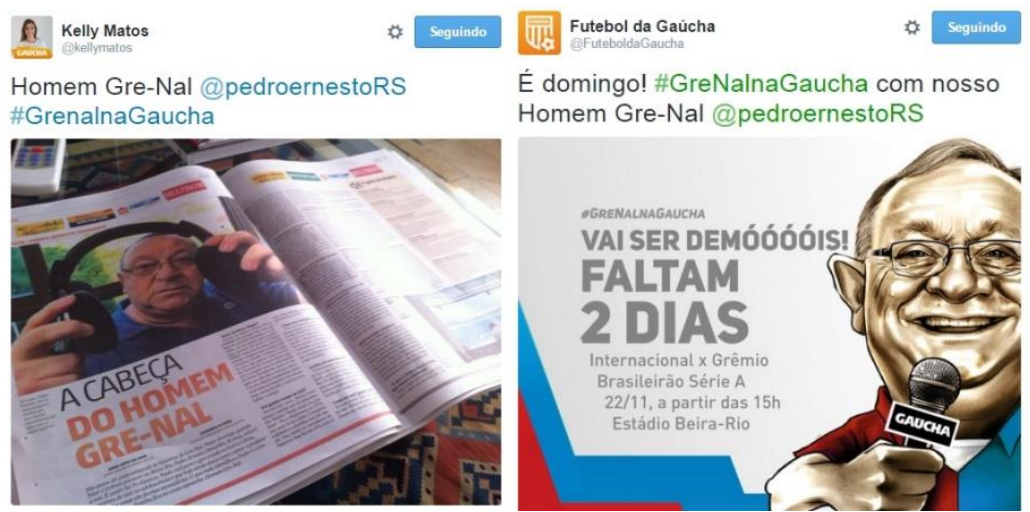

Fonte: www.twitter.com/kellymatos Fonte: www.twitter.com/FuteboldaGaucha

A análise da cobertura da partida, a partir dos tuítes do perfil @FuteboldaGaucha e também dos retuítes de seus jornalistas feitos pelo mesmo, contam com um pré-jogo, com relato da partida e também com o pós-jogo. Durante esse período, 158 mensagens foram publicadas pela Rádio Gaúcha, dando conta dos acontecimentos do GreNal 408. 
Figura 5. A movimentação dos jornalistas na cobertura esportiva no Twitter da rádio

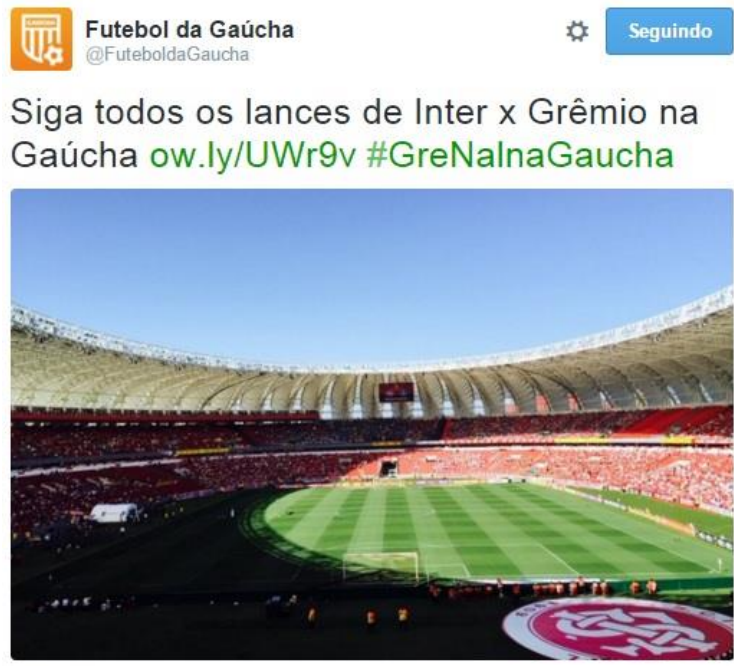

Fonte: www.twitter.com/FuteboldaGaucha

Durante a cobertura da partida, a equipe de jornalistas, em cada inserção ao vivo na rádio, ressaltava o perfil @ FuteboldaGaucha e também seus perfis pessoais, visando constituir e manter a sua comunidade de ouvintes-internautas (VIDELA-RODRÍGUEZ, PIÑEIROOTERO, 2013), a partir dos seguidores que cada um dos profissionais possuía em sua conta na rede social. Eles publicaram fotos e vídeos relacionados ao clássico na rede social e também utilizaram ferramentas de interatividade em tempo real, como o aplicativo Periscope ${ }^{4}$, que permite emissão de conteúdo audiovisual em streaming, conforme tuíte (figura 6) do jornalista Luciano Périco, que integra a equipe de esportes da Rádio Gaúcha. A publicação se configura como uma característica do rádio hipermidiático (LOPEZ, 2009), estruturando-se como uma estratégia discursiva utilizada pelos jornalistas a fim de atrair os seguidores para a rede social e, se possível, para a audição da cobertura radiofônica em qualquer dispositivo que o permitisse.

Figura 6. O Periscope funciona como mais um dispositivo de captura dos ouvintes

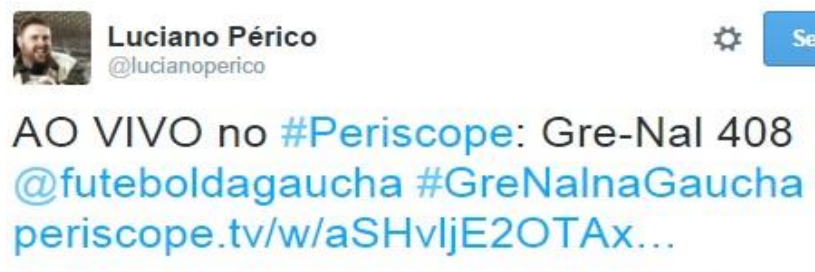

Fonte: www.twitter.com/lucianoperico

\subsection{A RÁDIO GUAÍBA AM 720 E FM 101.3}

\footnotetext{
${ }^{4}$ Aplicativo para dispositivos móveis disponível no Google play e Apple Store.
} 
A Rádio Guaíba, ao contrário da emissora concorrente, optou por uma hashtag genérica, ou seja, não foi criada uma específica para a cobertura do jogo no Twitter, mas manteve aquela já usada para fortalecer o nome da rádio na rede social. A \#LigaNaGuaiba é comumente utilizada pela emissora para qualquer cobertura jornalística. Embora não tenha construído uma hashtag exclusiva, a Rádio Guaíba aproveitou os espaços multimidiáticos do Grupo Record para ampliar a visibilidade da mesma e legitimar ainda mais o seu nome com o intuito de captar a atenção dos ouvintes-internautas e levá-los à audição da frequência radiofônica e acompanhamento da transmissão online por meio da rede social. A \#LigaNaGuaiba, durante o período analisado, teve 1.052 menções e foram utilizadas como no seguinte exemplo:

Figura 7. A hashtag da emissora foi atrelada à menções sobre a performance do narrador

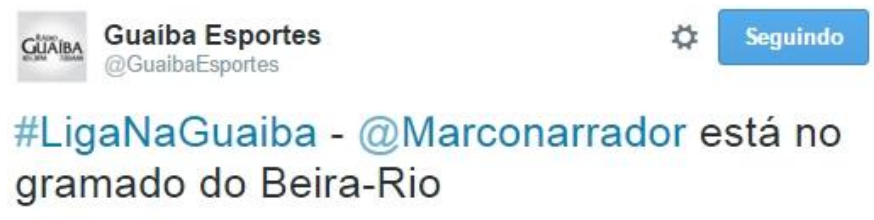

Fonte: www.twitter.com/GuaibaEsportes

Embora a hashtag se constitua como uma estratégica discursiva eficiente de captura, a Guaíba preferiu enfatizar, como jamais antes feito, a ampliação da visibilidade da contratação e estreia do narrador Marco Antônio Pereira. Desde o dia 20 de novembro, menções no Twitter foram direcionadas à performance do narrador. Mais do que a concorrente, a Guaíba enfatizou a contratação do profissional (antes ele trabalhava na Rádio Gaúcha) que ganhou autoridade por meio das estratégias discursivas lançadas na rede social, estabelecendo fluxos interativos nos quais a autorreferencialidade aparece com marca significante do poder de comunicação e de engajamento de ouvintes-internautas (KROTH, 2012) do narrador.

No Twitter, enquanto se autorreferenciou, Marco Antônio Pereira foi construindo uma dinâmica de operações de sentido a qual conectou seguidores da rede social da emissora com a transmissão da rádio no dial. As conexões são ocasionadas pelo trabalho enunciativo do narrador da Guaíba que reverberou as ações que estavam em andamento, ou seja, ensejou sua performance, legitimando a qualidade pessoal e dos seus cúmplices (a equipe esportiva) na transmissão da cobertura futebolística. Foram 19 menções sobre o narrador a partir do perfil oficial da rádio, além de 26 tuítes com a hashtag \#MarcãoNaGuaiba e do perfil @ Marconarrador, que pertence ao narrador Marco Antônio Pereira. 


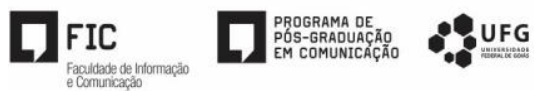

Antes da transmissão do clássico, o radialista participou de diversos programas da emissora. Dessa forma, a exploração da performance do narrador constituiu-se como a principal estratégia discursiva midiática da Rádio Guaíba com o intuito de captar o público para sua transmissão radiofônica. O perfil @GuaibaEsportes retuítou todos os registros dos jornalistas da emissora em torno da estreia de Marco Antônio Pereira. Um dos mais retuítados foi o post do jornalista Carlos Guimarães, que registrou em vídeo, na rede social (figura 8), a abertura da jornada esportiva da Guaíba, na qual o narrador fala: "Eu estou muito emocionado... Deus é testemunha do quanto eu quis viver esse momento". Na sequência, ele abre a transmissão direto do Estádio Beira-Rio. Carlos Guimarães descreve, ainda no mesmo tuíte, que este é um "momento histórico".

Figura 8. O ouvinte-internauta teve acesso a um vídeo disponibilizado no Twitter

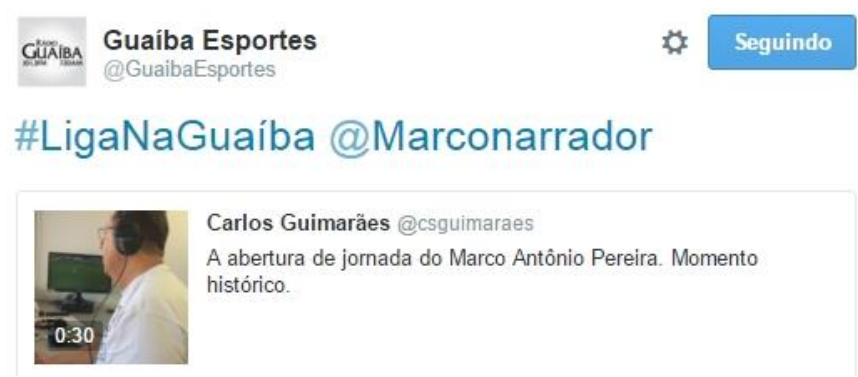

Fonte: www.twitter.com/GuaibaEsportes

A cobertura do Gre-Nal no Twitter, assim como na Rádio Gaúcha, também foi feita por meio do perfil esportivo da emissora e por seus jornalistas. As publicações dos mesmos foram retuítadas pelo perfil @GuaíbaEsportes. Durante o período entre o pré e pós-jogo, foram 130 mensagens publicadas. O conteúdo destas mensagens trazia informações de bastidores, como o movimento da torcida, dos técnicos, dos jogadores, as escalações, entrevistas com atletas e torcedores, e, também, da equipe esportiva que narrava os lances da partida para quem estava acompanhando a transmissão no Twitter. Neste sentido, a emissora preocupou-se em ampliar a visibilidade da cobertura pela rede social com vistas a reforçar a marca da Guaíba e, assim, constituir mais um importante contrato de leitura (FLECK, FERRARETTO, 2015). Não habitual, também, foi a participação de toda a equipe esportiva da emissora na produção de conteúdos para o Twitter, alterando, de certo modo, a rotina produtiva dos profissionais da emissora. Foram escalados repórteres por time de futebol, dois comentaristas, o narrador e dois repórteres acompanhavam a movimentação da torcida, além de toda equipe técnica. 


\section{CONSIDERAÇÕES FINAIS}

A partir da análise, que se baseou no que compreende como estratégias discursivas midiáticas utilizadas pelas emissoras de rádio, evidenciou-se que cada uma das emissoras fazem uso peculiar do Twitter. Tanto no dia a dia observado no período pré-jogo, quanto em acontecimentos com cobertura especial, como o Gre-Nal 408.

As rádios Gaúcha e Guaíba partem do pressuposto de que o Twitter é uma ferramenta a mais para captar e fidelizar os ouvintes-internautas em suas transmissões, porém, como demonstrado na pesquisa, fazem uso pouco eficiente da ferramenta. Gaúcha e Guaíba não utilizaram uma das principais marcas do Twitter que é possibilidade de comunicação instantânea, ou seja, de dar fluxo à conversação entre os produtores e ouvintes-internautas. Nos tuítes que compuseram a análise, observou-se que o perfil @FutebolDaGaúcha apenas emite as mensagens - próprias e, a partir de retuítes de sua equipe -, publica fotografias e faz uso de hashtags e hiperligações para que os usuários que os acompanham na rede social, consumam outros produtos produzidos por eles.

Já o perfil@GuaibaEsportes, além de repetir o que faz emissora a concorrente, apresenta uma tímida forma de interatividade com seu ouvinte-internauta, ao apenas curtir as publicações emitidas por este público que menciona o perfil ou a \#LigaNaGuaíba, demonstrando que o gerenciador somente leu a mensagem publicada pelo usuário.

Apesar de fazerem uso de imagens e vídeos, ainda são pouco valorizadas as características do ecossistema digital. Há defasagem em relação a publicações multimidiáticas. Também percebe-se que a proposta de estabelecer um fluxo de conversação e compartilhamento de conteúdos seria uma forma de valorização da audiência e de aproveitamento dessa interatividade proposta pela rede social, estreitando laços com os consumidores de seu principal produto, que é a emissão radiofônica. Nesse sentido, as estratégias discursivas midiáticas de captura e fidelização de ouvintes-internautas utilizadas pelas rádios por meio do uso do Twitter ainda podem ser mais eficientes.

Os retuítes que, conforme apresentados durante o texto, podem gerar um efeito de rede, chegando a milhares de usuários, mesmo que estes não sejam seguidores do perfil originário, seriam mais uma forma de compartilhar materiais diferenciados e criar momentos de interatividade entre produtor e consumidor de informações. Porém, as mensagens que foram retuítadas por esses perfis são apenas de profissionais das emissoras, o que, na maioria das vezes, acaba gerando uma repetição de conteúdo, ao invés da ampliação e qualificação dessa difusão. 
Enfim, as características da convergência midiática ainda são pouco exploradas como um recurso estratégico na estruturação de conteúdos capazes de atrair usuários para o consumo de informações. Para que as emissoras consigam fazer um uso satisfatório do contexto convergente de produção e consumo de mídia, e, neste caso especial, do uso do Twitter, é necessário que haja um planejamento da articulação dos conteúdos entre a produção radiofônica e os disponibilizados na rede social. Mais do que um mero meio de divulgação institucional e ampliação da visibilidade de conteúdos, como evidenciado nesta pesquisa, o Twitter, assim como outras redes sociais, pode ter outras funcionalidades importantes para o rádio, como instrumento de apuração de informações, mensuração do consumo, legitimação da marca e a constituição de vínculos com a audiência.

\section{REFERÊNCIAS}

CAGLIARI, A.; ZANOTTI, C. A. A participação dos ouvintes/internautas via Twitter na formação da programação da CBN Campinas. Anagrama, USP, n², ano 2012. Disponível em: <http://goo.gl/q3Qnrv>. Acesso em: 25 nov. 2015.

CANAVILHAS, J. Hipertexto e recepção de notícias online. Biblioteca on-line de Ciências da Comunicação da Universidade da Beira Interior. 2014. Disponível em: <http://goo.gl/FKo1fV> Acesso em: 10 dez. 2015.

CEBRIÁN HERREROS, M. La radio en la convergencia multimedia. Barcelona: Editorial Gedisa, 2001.

CEBRIÁN HERREROS, M. O rádio no contexto da comunicação multiplataforma. RádioLeituras, UFOP, n.02, ano 2, 2011. Disponível em: 〈https://goo.gl/gff96F>. Acesso em: 24 nov. 2015.

FAUSTO NETO, A. A deflagração do sentido. Estratégias de produção e de captura da recepção. In: SOUZA, Mauro W. (Org). Sujeito, o lado oculto do receptor. São Paulo: Brasiliense, 1995.

FERRARETTO, L. A. Alterações no modelo comunicacional radiofônico: perspectivas de conteúdo em um cenário de convergência tecnológica e multiplicidade de oferta. In: FERRARETTO, Luiz Artur e KÖCKNER, Luciano (Orgs). E o rádio? Novos horizontes midiáticos. Porto Alegre: EdiPUCRS, 2010. Disponível em: 〈http://goo.gl/1MlBdx> . Acesso em: 03 dez. 2015.

FERRARETTO, L. A.; FLECK, P. Radiojornalismo e convergência: um estudo do uso das redes sociais nas rádios CBN, de São Paulo, e Gaúcha, de Porto Alegre nas eleições de 2014. In: CONGRESSO BRASILEIRO DE CIÊNCIAS DA COMUNICAÇÃO. 38., 2015, Rio de Janeiro. Anais... São Paulo: Sociedade Brasileira de Estudos Interdisciplinares da Comunicação, 2015. Disponível em: 〈http://goo.gl/uzZMEc〉 Acesso em: 25 nov. 2015. 
HAUSSEN, D. F. O jornalismo no rádio atual: o ouvinte interfere? In: FERRARETTO, Luiz Artur e KÖCKNER, Luciano (Orgs). E o rádio? Novos horizontes midiáticos. Porto Alegre: EdiPUCRS, 2010. Disponível em: <http://goo.gl/1MlBdx> . Acesso em: 03 dez. 2015.

KISCHINHEVSKY, M. Estratégias enunciativas da Rádio CBN e etiquetagem de conteúdos - A cobertura via internet do desabamento de prédios no Centro do Rio. In: CONGRESSO BRASILEIRO DE CIÊNCIAS DA COMUNICAÇÃO. 35., 2012, Fortaleza. Anais... São Paulo: Sociedade Brasileira de Estudos Interdisciplinares da Comunicação, 2012. Disponível em: 〈http://goo.gl/qFX0TR>. . Acesso em: 24 nov. 2015.

KROTH, M. E. Contratos de leitura: narrativas do cotidiano como estratégia de captura e recepção no rádio. Biblioteca on-line de Ciências da Comunicação da Universidade da Beira Interior. 2010. Disponível em: 〈http://goo.gl/TRhO1H>. Acesso em: 03 dez. 2015.

KROTH, M. E. O rádio como dispositivo de midiatização do social: um estudo do programa João Carlos Maciel, Santa Maria, RS. 209f. Tese (Doutorado em Ciências da Comunicação). Universidade do Vale do Rio dos Sinos, São Leopoldo, 2012.

LOPEZ, D. Radiojornalismo hipermidiático: tendências e perspectivas do jornalismo e rádio all news brasileiro em um contexto de convergência tecnológica. 299f. Tese (Doutorado em Comunicação e Cultura Contemporâneas). Universidade Federal da Bahia, Salvador, 2009.

LOPEZ, D. Radiojornalismo hipermidiático: tendências e perspectivas do jornalismo e rádio all news brasileiro em um contexto de convergência tecnológica. Covilhã: Labcom, 2010. Disponível em: 〈http://goo.gl/0zKzb9>. Acesso em 03 dez. 2015.

MANOVICH, L. El lenguage de los nuevos medios de comunicación. Buenos Aires: Paidós, 2006.

PRATA, N. Webradio: novos gêneros, novas formas de interação. 395f. Tese (Doutorado em Linguística Aplicada). Universidade Federal de Minas Gerais, Belo Horizonte, 2008. Disponível em: <http://goo.gl/FJVyhx> . Acesso em: 25 out. 2015.

PRATA, N.; CAMPELO, W.; SANTOS, M. C. A utilização das redes sociais pelo rádio mineiro. In: ENCONTRO NACIONAL DE PESQUISADORES EM JORNALISMO, 8. 2010, São Luís. Anais... São Luís: Associação Brasileira de Pesquisadores em Jornalismo, 2010. Disponível em: < http://goo.gl/R0r5QM>. Acesso em: 03 dez. 2015.

RECUERO, R.; ZAGO, G. Em busca das "redes que importam": redes sociais e capital social no Twitter. Líbero, v.12, n, 24, 2009.

ROCHA, G. O. O poder do Twitter como ferramenta de Comunicação. 50f. Trabalho de Conclusão de Curso. Faculdade de tecnologia e ciências sociais aplicadas (UniCEUB). Brasília, 2010. Disponível em: <http://goo.gl/5uSWLd> Acesso em: 03 maio 2015.

SALAVERRÍA, R. Redacción Periodística em Internet. Pamplona: Ediciones Universidad de Navarra, S.A, EUNSA, 2005. 
口fic

SANTOS, G. P. A mudança nas rotinas de produção do radiojornalismo a partir do uso do Twitter: o caso da Rádio Gaúcha. 127f. Dissertação (Mestrado em Comunicação Social). Pontifícia Universidade Católica do Rio Grande do Sul, Porto Alegre, 2013. Disponível em: <http://goo.gl/OIilsS> . Acesso em: 03 dez. 2015.

SCOLARI, C.; et al. "The Barcelona Mobile Cluster: Actors, Contents and Trends". International Journal of Interactive Mobile Technologies, iJIM. nº 3, 2009. Disponível em: 〈http://goo.gl/S5Hfo7> . Acesso em: 07 out. 2015.

VERÓN, E. Fragmentos de um tecido. São Leopoldo: Editora Unisinos, 2004.

VIDELA RODRÍGUEZ, J. J.; PIÑEIRO OTERO, T. Hacia una "radio social”. Interacción, proyección y repercusión de las cadenas españolas en las redes sociales, In: Revista científica de Comunicación y Tecnologías emergentes, Icono 14, n.02, 2015. Disponível em: <http://goo.gl/IBvVG2> . Disponível em: 29 nov. 2015. 